\title{
HUME, LIBERTY AND THE OBJECT OF MORAL EVALUATION
}

\begin{abstract}
André Klaudat ${ }^{1}$
“'Is he free?'- well, what have you in mind that he might be instead? In prison? Tied up in prison? Committed to a prior engagement?"

J.L.Austin, Sense and Sensibilia, p.15n2.

"Part of the wonderful character of the works we study is the depth and variety of ways they can speak to us. I don't want to do anything to interfere with their doing that. So if I present an interpretation, it is not only to try to illuminate the writer's background scheme of thought but also to encourage you to work out a better interpretation, one that is sensitive to more features of the text than mine, and makes better sense of the whole".

John Rawls, Lectures on the History of Moral Philosophy, p.18.
\end{abstract}

RESUMO $O$ projeto de Hume em relação ao conflito entre liberdade e necessidade é "reconciliatório". Mas qual é a natureza do projeto de Hume? Resolve ele um problema que diz respeito à metafísica somente? E quando Hume afirma que a disputa entre as doutrinas da liberdade e da necessidade é meramente verbal, quer ele dizer que não há nenhuma disputa metafísica genuína entre as doutrinas? No presente trabalho eu argumento a favor de (1) que há lugar para a liberdade na filosofia de Hume, e não somente porque a posição é pro forma compatibilista, mesmo que isto tenha importância para o reconhecimento de que a preocupação maior de Hume em relação ao assunto é com a prática; (2) que a posição não involve uma "subjetivização" de toda forma de necessidade: ela não é compatibilista porque cria um espaço para a afirmação de que as operações da vontade são não-problematicamente necessárias através de um enfraquecimento da noção de necessidade como ela se aplica

1 Universidade Federal do Rio Grande do Sul. Artigo recebido em setembro e aprovado em outubro.

KRITERION, Belo Horizonte, no 108, Dez/2003, p.191-208 
aos objetos externos; (3) que Hume sustenta que o fenômeno ordinário da causação mental não torna impossível a atribuição de responsabilidade moral, o que se adapta perfeitamente bem a identificação de Hume do objeto da avaliação moral: o todo do caráter de uma pessoa, em relação ao qual há, não obstante, liberdade. Eu pretendo embasar minhas assertivas através de uma leitura atenta ao que Hume afirma na seção 8 da primeira Investigação.

Palavras-chave: Hume, liberty, moral evaluation

ABSTRACT Hume's project concerning the conflict between liberty and necessity is "reconciliatory". But what is the nature of Hume's project? Does he solve a problem in metaphysics only? And when Hume says that the dispute between the doctrines of liberty and necessity is merely verbal, does he mean that there is no genuine metaphysical dispute between the doctrines? In the present essay I argue for: (1) there is room for liberty in Hume's philosophy, and not only because the position is pro forma compatibilist, even though this has importance for the recognition that Hume's main concern when discussing the matter is with practice; (2) the position does not involve a "subjectivization" of every form of necessity: it is not compatibilist because it creates a space for the claim that the operations of the will are non-problematically necessary through a weakning of the notion of necessity as it applies to external objects; (3) Hume holds that the ordinary phenomena of mental causation do not preempt the atribuition of moral responsibility, which combines perfectly with his identification of the object of moral evaluation: the whole of the character of a person, in relation to which there is, nonetheless, liberty. I intend to support my assertions by a close reading of what Hume states in section 8 of the first Enquiry.

1. Readers of section 8 of Hume's first Enquiry ("Of Liberty and Necessity") and of the corresponding sections of the Treatise (1 and 2 of Part 3, Book II) will be interested in the following questions: what is Hume trying to achieve in these places? What is he trying to show? And we get only the start of a story by statements as "to present and defend the thesis of the compatibility of freedom and necessity" or, to use Hume's own phrase, "to execute the 'reconciling project' which consists in defending both the 'doctrine of necessity' and 'the doctrine of liberty" "2. What we really want to know is what is the specific nature of this

2 Section 8 states this explicitly (E pp.81, 95, 97). In the Treatise (p.407), Hume had implied that the "doctrine of liberty" is either absurd or else unintelligible. No other option seems to have been left at the time of the Treatise. Does section 8 of the Enquiry represent a change of position? I will quote Hume's two works as 
"Humean Compatibilism". The interest in the latter question is also awakened by one's simple recognition - against what certain parts of Hume's text might suggest - that Hume's treatment of freedom is complex, for it involves many distinct but related issues in metaphysics and moral philosophy.

2. One could be interested in freedom in Hume from the point of view of moral philosophy exclusively. Then, one should take notice that the topic receives attention in parts of the works which are speculative or theoretical. This fact should tell us something. What? That freedom is perhaps not such an important notion for what Hume takes to be the proper treatment of morality. This opens up the possibility, which I only mention now, that Hume's way with morality may offer some really important considerations for the correct understanding of freedom in his philosophy.

One good reason, however, for treating freedom in an investigation of Hume's moral philosophy would be that Hume's defense of the unanimity about the "doctrine of necessity" concerns the foundation of morals, and this could corroborate the view that the nature of Hume's project also in this area of morality, of what can move us to action, is to build a science of moral sentiments, that is, Hume would be interested only in an explanation of the phenomena of morality ${ }^{3}$. Now, as it seems possible to have serious doubts about this exclusivistic approach, one might then be willing to examine what Hume holds about freedom in order to see whether it takes one inevitably to a project of explanation in moral philosophy.

3. In order to get at what I take to be fundamental in Hume's position about liberty, I will proceed in three stages. In the first stage, I will present what strikes the eye in a superficial but not inattentive contact with section 8 of the first Enquiry. And I should state at once that I will center my analysis very closely on how Hume develops his argument in this text. Hume would be presenting the "doctrine of necessity" as taking due care of everything that is of importance concerning action, motivation and the operations of the will. From this perspective, there wouldn't be any real liberty.

In the second stage, we wouldn't be willing to deny the existence of liberty in a sense. Given that Hume names his project a "reconciling project" and defends the notion of a "liberty of spontaneity" in the Treatise and of a "hypo-

follows: T=Treatise (Selby-Bigge/Nidditch, Oxford U.P., 1978); E=Enquiries (Selby-Bigge/Nidditch, Oxford U.P., 1975), followed by page number. I will quote from the "second" Enquiry using EPM. 3 Cf. Jerome Schneewind, The Invention of Autonomy, chapter 17: "Hume: Virtue Naturalized" (Cambridge,
Cambridge U.P., 1998, pp.354-77). 
thetical liberty" in the first Enquiry, it would be necessary to take into account a conception of liberty that has to be accomodated along side the speculative results about what can be necessity for us humans. It would be exactly Hume's views on this latter matter - of which the essential elements would be "constant conjunction" and "inference" — that would put him in a positon to offer a plausible account of freedom too. This account would make our vision of the free operation of our wills compatible with an understanding that everything that happens in the world has a determinant cause. As presented in the second stage, Hume's conception of the necessary connexion between cause and effect would be "regularity" cum subjective effect. I think it would be proper to call this the "metaphysico-subjetivistic" view of Hume on necessary connexion.

This view could then be applied to a new sphere of "objetcs", i.e. of the "internal objects", not that of the "external objects" (cf. E pp.86, 89), with the result that "actions and volitions of intelligent agents", or "internal principles and motives" (E p.88) would operate - given their manner of operation: with uniformity and regularity - with necessity. But, even though we would speak of a necessity of determination with regard to an operation, it would concern the determination of the operation of the will. This would be extremely important, for in stating that the phenomena in question concern the will we would be able to conceive it as free. We would only have to provide for the nonexistence of impediments of a specific type (not being a prisoner or being in chains, cf. E p.95) and consequently we would have "a power of acting or not acting, according to the determinations of the will" (E p.95). This is in fact Hume's definition of this liberty he calls "hypothetical".

In the third stage, to begin with, the "subjectivization" of every necessity that took place in the previous stage will be resisted. I will hold the view that if we keep the distinction between the two spheres of "objects" (the "external" and the "internal") we will be able to see that the necessity of the operation of the "internal objects" is compatible with the freedom of which we speak when we are interested in what really matters from a Humean approach: the attribution of merit to persons with a character that is their own. From a such viewpoint, what really matters concerns our ordinary lifes, and in these the uniformity and regularity, which Hume so much insists on, can be given their proper, and important, place. But we would be talking of a whole that is constituted by the phenomena we ordinarily call mental causes. In this third stage I will indicate where we should look to find what I take to be the specific nature of compatibilism Hume's fashion. It will be importa to keep in mind the "dialectic" of the argument I will be presenting. Positions are tentatively ascribed to Hume at earlier stages, at the end they are not taken as his considered view. 
4. In the beginning of the second part of section 8, Hume talks about a possibility concerning what he has been presenting: that his hypothesis would have dangerous consequences for religion and for morality. On what is he thinking? It can only be that his considerations about necessity would imply that there is no liberty to human beings and their actions. And if that were the case, then there would be neither merit nor moral responsibility. But what of what Hume said earlier could have made anyone think that he denies reality to the latter notions?

Firstly, Hume starts his treatment of the subject with an examination of the "doctrine of necessity". This doctrine is presented as a view of what happens to matter, but it seems to concern every movement in nature (cf. E pp.812 ), that is, everthing which is an "operation of bodies". Hume says that "[i]t is universally allowed that matter, in all its operations, is actuated by a necessary force, and that every natural effect is as precisely determined by the energy of its cause that no other effect, in such particular circumstances, could possibly have resulted from it" (E p.82). The picture is of the complete determination of a mechanism. Hume in the immediate continuation presents the point with poignancy: "The degree and direction of every motion is, by the laws of nature, prescribed with such exactness that a living creature may as soon arise from the shock of two bodies, as motion, in any other degree or direction than what is actually produced by it" (E p.82). What Hume seems to be meaning here is the following: that causes and causal processes involve "natural powers" which are such that when they are actuated can not fail to produce the effects that are expected from them. Fire has the power of consuming inflamable material. We only have to put the stuff in contact with fire and it will be consumed. In this type of case, conditions of "opportunity" are conditions for the exercise of the power (of the "capacity"). What can not happen here is that an alternative takes place, i.e. there doesn't seem to be any freedom concerning the operations of the powers in question. He seems also to be meaning with this that in the operation of "natural powers" there is a complete and specific determination of the results of the operation.

In the second place, and following in the same line, Hume explains why we are lead ordinarily - the "vulgar" seems to be able only too often to make this mistake - to attribute an "uncertainty of events" to an "uncertainty in the causes" (E p.86). Because we do not take into account that there is "a vast variety of springs and principles, which are hid, by reason of their minuteness or remoteness", which makes the credit of the "contrariety of events" to go not to "any contingency in the cause", but rather - what seems to be unsuspected by the vulgar - to "the secret operation of contrary causes". That is what 
happens with the peasant who doesn't know that the mechanism of a clock stopped in its movements because of a grain of dust. From cases as this philosophers derive - and they act properly in so doing, that seems to be Hume's point - the maxim that "the connexion between all causes and effects is equally necessary, and that its seeming uncertainty in some instances proceeds from the secret opposition of contrary causes" (E p.87). This type of approach also accounts - so Hume seems to think — for why the study of medicine can not be as full of practical consequences as we would like it to be: "[The] human body is a mighty complicated machine" (E p.87). What is the natural suggestion that accompanies this point about medicine? That the same approach can be adopted in relation to the lack of uniformity, the inconstancy, the irregularity of actions and volitions of intelligent agents (cf. E p.88). With what would we be committed at bottom in holding such a view? In Hume's own words: "[T] hat the conjunction between motives and voluntary actions is as regular and uniform as that between the cause and effect in any part of nature" (E p.88). Also in the case of actions and volitions we would not need, because of the phenomenon of the "uncertainty of events" to give up the view that the "energy of [their] cause" has "necessary force" (cf. E p.82), and so that there would not be au fond any liberty.

Now, in the third place, it seems to me that the considerations by Hume that point more vigorously to the vision that everything that happens is determined are those about chance (E pp.95-6), of which the conclusion is that "liberty, when opposed to necessity, not to constraint, is the same thing with chance; which is universally allowed to have no existence". Well, liberty, so it seems to many, is opposed to necessity. Consequently, Hume would hereby be denying the existence of liberty. In the Treatise, the "liberty of indifference" is that linked with the concept of chance and is the "negation of necessity and causes" ( $T$ p.407). There Hume seems to believe that it is not a "real existence", and that it is mistaken with the only liberty "which it concerns us to preserve": liberty of spontaneity (cf. T pp.407-8). In this section of the Treatise, Hume would state quite clearly that which his defense of the "doctrine of necessity" would commit him to. He says: "After we have perform'd any action; tho' we confess we were influenc'd by particular views and motives; 'tis difficult for us to perswade ourselves we were govern'd by necessity, and that 'twas utterly impossible for us to have acted otherwise" (T p.407, my emphasis). It is precisely this way of putting the point that makes one think that for Hume to have acted otherwise is as probable as that from the shock of two bodies should have arisen a living creature. That is, Hume seems to be committed to making necessity to account for everything that happens, including 
the actions of human beings, the "intelligent agents". And in doing this, he seems to be making liberty impossible, given that it was utterly impossible for us to have acted otherwise. This was presented in an ex post facto fashion (but it is only a way of making the point). Accordingly, which vision does it offer of what we can do ante facto? That in truth we have no freedom to act.

A last remark about the first stage in the attempt to understand Hume's position. It concerns a comparison I think it is worthwhile making at this point. Think of the physicalism of Donald Davidson's Anomalous Monism (AM) ${ }^{4}$. Mental events are physical events. From an ontological point of view, everything that exists is constituted of what is physical, even though it can not in a certain sense be reduced to the physical. Now, consider the element of causality in AM. In spite of the fact that the "causal relation" is an extensional relation between particulars, that is, events are causally related no matter how they are described, AM is committed to the principle of the "nomological character of causality". This means that we will only believe that particular events are related causally if there is a law that covers these events that are in the causal relation, but that without the further requirement - which gives to AM its special mark - that the particular events be identified, described, in the same vocabulary in which the law is expressed. This makes it possible to hold, according to Davidson, that the causation of mental events is somehow captured by what can be stated in the vocabulary of a physics that only posits physical events. This is in order because after all mental events are physical events, and Davidson argues that the mental vocabulary can not be handled in a "closed [and complete] system" which would allow for the formulation of "strict laws". From the physical point of view, we would be in possession of a vocabulary which would be dealing with all the events there are as physical events, because that is what they are ontologically, and from this perspective we would have a nomological determination of everything that happens. Despite Davidson's intentions — he wants to uphold a compatibilism — what comes to the fore is the confinement of freedom to a mentalistic vocabulary of reasons, beliefs, volitions and actions. Now, strong intuitions go against such a move. They would be given expression, for example, by Peter Geach when he says: "If physical circumstances describable without reference to my intentions enabled someone to predict what sound-waves [as speech I presume] came out of my mouth, then my freedom of speech would be a mere illusion" ${ }^{\text {. And }}$

4 "Acions, Reasons, and Causes" and "Mental Events" in: Essays on Actions and Events (Oxford: Clarendon Press, Oxford UP, 1980).

5 "Intention, Freedom and Predictability" in: Teichmann, R. (ed): Logic, Cause and Action, Essays in Honour of Elizabeth Anscombe, (Cambridge: Cambridge UP, 2000), p.79. 
this seems to be a real possiblity in AM. If Geach is correct, then we must be offered a much stronger qualification of the relation of the mental and the physical than the one we find in AM, which amounts to saying that at bottom the mental is a distinct vocabulary, autonomous, that answers exclusively to its own sources of evidence. Anthony Kenny seems to offer such a stronger qualification and I will mention it in another comparison at the end of stage two, to which I turn now.

5. In the second stage in the process of trying to reach a better understanding of Hume's position on liberty, there will be given full vent to the point that Hume is developing a "reconciling project", that according to him there is a satisfactory conception of freedom that is compatible with the "doctrine of necessity". The first move we will have to make to see things from the perspective of this second stage is to take note of what Hume holds about the necessity that characterizes everything that happens.

Hume would be leaving us in no doubt about what is the nature of the necessity of the connexion between cause and effect. Hume himself says: "Our idea, therefore, of necessity and causation arises entirely from the uniformity observable in the operations of nature, where similar objects are constantly conjoined together, and the mind is determined by custom to infer the one from the appearance of the other. These two circumstances form the whole of that necessity, which we ascribe to matter. Beyond the constant conjunction of similar objects, and the consequent inference from one to the other, we have no notion of any necessity or connexion" (E p.82). What strikes the eye in this official presentation of the Humean position on the nature of necessity? According to the view adopted in the second stage, the following.

We do not have any form of access to the operations of nature as they are in themselves, that is, neither by the senses, nor through any intellectual insight, do we reach these workings of nature. What we have to count on, and this is what makes it possible that we speak of the "production" of an object by another, is uniformity in the appearance of objects. So, negatively, we haven't got any metaphysical insight of the necessity in the objects. In the objects we only see, and from them we only get, uniformity of behaviour. However, this uniformity has consequence on us, and there is consequently an inference, a passage, a determination of an operation of the mind. This is the true impression of necessity, an "impression of reflexion": the determination of the mind of passing from one object to its usual attendant. Therefore, there is a determination that concerns the subjective, and then necessity should be located, if it should be located anywhere, only in the mind. This vision of Hume on neces- 
sity I call the "metaphysico-subjectivistic interpretation". However, what would Hume be doing with this kind of vision in his discussion of liberty?

Here we must proceed with care.

It is remarkable how many observations Hume makes concerning human motives and actions with the objective of making us notice the uniformity and regularity present in them. I offer some quotations:

a) "It is universally acknowledged that there is a great uniformity among the actions of men, in all nations and ages, and that human nature remains still the same, in its principles and operations. The same motives always produce the same actions: the same events follow from the same causes. Ambition, avarice, self-love, vanity, friendship, generosity, public spirit: these passions mixed in various degrees, and distributed through society, have been from the beginning of the world, and still are, the source of all the actions and enterprises, which have ever been observed among mankind" (E p.83).

b) "Mankind are so much the same, in all times and places, that history informs us of nothing new or strange in this particular. Its chief use is only to discover the constant and universal principles of human nature, by showing men in all varieties of circumstances and situations, and furnishing us with materials from which we may form our observations and become acquainted with the regular springs of human action and behaviour" (E p.83).

c) "So readily [given the previous example of dubious accounts of travellers and of what is the condition for us to trust history] and universally do we acknowledge a uniformity in human motives and actions as well as in the operations of body" (E. p.84).

d) "But were there no uniformity in human actions, and were every experiment which we could form of this kind irregular and anomalous, it were impossible to collect any general observations concerning mankind; and no experience, however accurately digested by reflection, would ever serve to any purpose" (E p.85).

e) "The most irregular and unexpected resolutions of men may frequently be accounted for by those who know every particular circumstance of their character and situation. A person of an obliging disposition gives a peevish answer: But he has the toothache, or has not dined" (E p.88).

f) "Thus it appears, not only that the conjunction between motives and voluntary actions is as regular and uniform as that between the cause and effect in any part of nature; but also that this regular conjunction has been universally acknowledged among mankind, and has never been the subject of dispute, either in philosophy or common life" (E p.88). 
There are also those two famous examples that try to show how natural and moral evidences work together to form only one chain of argument: the case of the prisoner who is going to be executed and the case of the purse full of gold on the pavement at Charing Cross. These are well known.

However, where do we stand with this reminder of such an impressive uniformity in the relations between motives and action of intelligent agents? We still have to take care. Take the following rather long quotation from Hume:

\begin{abstract}
"It would seem, indeed, that men begin at the wrong end of this question concerning liberty and necessity, when they enter upon it by examining the faculties of the soul, the influence of the undertanding, and the operations of the will. Let them first discuss a more simple question, namely, the operations of body and of brute unintelligent matter; and try whether they can there form any idea of causation and necessity, except that of a constant conjunction of objects, and subsequent inference of the mind from one to another. If these circumstances form, in reality, the whole of that necessity, which we conceive in matter, and if these circumstances be also universally acknowledged to take place in the operations of the mind, the dispute is at an end; at least, must be owned to be thenceforth merely verbal. But as long as we will rashly suppose, that we have some farther idea of necessity and causation in the operations of external objects; at the same time, that we can find nothing farther in the voluntary actions of the mind; there is no possibility of bringing the question to any determinate issue, while we proceed upon so erroneous a supposition. The only method of undeceiving us is to mount up higher; to examine the narrow extent of science when applied to material causes; and to convince ourselves that all we know of them is the constant conjunction and inference above mentioned. We may, perhaps, find that it is with difficulty we are induced to fix such narrow limits to human understanding: But we can afterwards find no difficulty when we come to apply this doctrine to the actions of the will. For as it is evident that these have a regular conjunction with motives and circumstances and characters, and as we always draw inferences from the one to the other, we must be obliged to acknowledge in words that necessity, which we have already avowed, in every deliberation of our lives, and in every step of our conduct and behaviour" (E pp.93-4).
\end{abstract}

What would be the point of this passage from the perspective of the second stage in which we find ourselves at the moment?

Hume would have deflationed the conception of necessity which we locate in matter. There wouldn't be any element of necessity in the operation of the external objects. Necessity would have been "subjectivised", it would have been brought to the interior of the mind. And, with this extremely important result, we would have been freed from the conception of necessity as "something farther" that we could find in the external objects, in matter, "something farther" which we not presume to be present in the voluntary actions of the mind, and exactly because of this - being freed from this "something more" in matter - we would be able to attribute necessity also to the actions of the will. 
So, the deflationary conception - actually the "metaphysico-subjectivistic interpretation" - would create a space for the attribution of necessity to the actions of the will (also in the case of the "fantastical desire of shewing liberty", which amounts to an ill-conceived attempt of proving the "doctrine of liberty" taken as a liberty of indifference, cf. E p.94n1). But, how does this allow any attribution of liberty to these actions of the will? How does the reconciling proceed? Hume himself makes exactly this question at this point, after stating that all humanity has always agreed with both the "doctrine of liberty" and the "doctrine of necessity": "For what is meant by liberty, when applied to voluntary actions?" (E p.95). And he gives his answer after stating what we do not want, according to him, to give up in facing such a question, to wit: "We cannot surely mean that actions have so little connexion with motives, inclinations, and circumstances, that one does not follow with a certain degree of uniformity from the other, and that one affords no inference by which we can conclude the existence of the other. For these are plain and acknowledged matters of fact" (E p.95). Hume's answer follows suit: "By liberty, then, we can only mean a power of acting or not acting, according to the determinations of the will; that is, if we choose to remain at rest, we may; if we choose to move, we also may" (E p.95).

So, liberty of the will is action in accordance with the determinations of the will. That the will operates via "determinations" is not detrimental to its liberty in so far as these determinations are of the will. That what we do be the result of our inclinations and motives, this is all there is in the case. The liberty of actions which originate in the will has to do with a causal necessary chain which is internal (it seems even that it must be internal to the will, not being enough that it is internal to the mind, given that supposedly we could lose our freedom through mental impediments). By making liberty to concern the internal world, Hume could assert that there is liberty because it is only with this type of determination - the internal type - that we are especifically concerned. In the world, in all of it, there is no chance, but there is this internal determination which is liberty on the conditon that there be no external constraint, which in the majority of cases is the limitation of what men can do through the means of external objects. This would be the kernel of Hume's view of the compatibility of liberty and necessity according to the second stage. At this point I would like to make another comparison.

It does not seem to me that this species of compatibilism is an unappealing philosophical approach. There seem to be several elements of value in what has been presented, even though we can not be quite clear about whether with this compatibilism we are nearer to Carl Hempel or to Donald David- 
son $^{6}$. Be that as it may, with what has been said can we really escape an accusation that genuine freedom was made impossible? Anthony Kenny seems to think that we can not. The position of this philosopher offers the stronger qualification that I mentioned earlier was needed and wasn't to be found in Davidson. And I present it in the spirit of a comparison which shows differences.

Kenny insists against compatibilists of the type we encountered in stage 2 that we have to conceive of freedom as "the power to do otherwise if one wants to" . This is so because "it cannot be true that one acted because one wanted to unless one had in some measure and at some point the ability to act otherwise than one did". Now this is a move by Kenny against those who he calls psychological determinists ("For an action to be free (...) it is enough for it to be done because it was wanted; and for it to be done because it was wanted, it is enough that it should have been caused by the want"). He doesn't mean to imply, however, that every form of determinism is incompatible with a power to do otherwise. This power requires, at the very minimum, that one has the power not to $\mathrm{X}$, which should be analysed as involving the opportunity not to do $X$ and the ability not to do X. Hereby Kenny reaches the point where the qualification concerning the relation between mind and body is in order, which is the main issue concerning the view we have reached in the second stage. He asks whether the power to do otherwise can be present if physiological determinism is true. The embarassing question would be: "Can I have the ability and opportunity not to do X if I am in a physiological state from which, in conjunction with physiological laws, it can be deduced that my body will move in such a way that I will do X?" Kenny meets the difficulty head on and answers "yes, I can".

Concerning ability, he argues that, as abilities are inherently general, one can fulfil the criteria for possessing them even in circumstances where one does not exercise the ability, and therefore it does not matter what the current physiological state of the person is.

Concerning opportunity, the issue is more intrincate. Suppose I had the opportunity to strangle my kitten but were actually in a physiological state which is such that I will not strangle him. Can I be said to have really the

6 Cf. John Bricke: "Hume, Freedom to Act, and Personal Evaluation" (in: Tweyman, S. (ed.): David Hume, Critical Assessments (Vol. IV) (London: Routledge, 1995) pp.175-91, for the interpretation of Hume as presenting a view of liberty practically identical with Davidson's conception of it as a "causal power". It seems that Bricke's presentation of compatibilism, in spite of the fact that it involves the clause "one couldn't have done otherwise", should be located in the second stage of my development. But, one should note, that perhaps the first stage could be assimilated without loss into the second, which is what motivates a discussion as the one that follows.

7 The Metaphysics of Mind (Oxford: Oxford UP, 1992) p.147. All quotations from Kenny are from pp.146-9 of this work. 
opportunity to do it? As it seems, nothing external prevents me, but isn't there something internal, in my brain, preventing me? Kenny doesn't think this is a successful objection to a compatibilism in this area. He argues as follows.

Firstly, "physiological determinism need in no way involve the theory that wants do not affect actions". By this Kenny means that it can not, because if it did it would go against what all of us take to be an established fact: that wants do affect actions. So, any "plausible physiological determinism" must make allowance for facts as that if I wanted to strangle my kitten I would. But then, secondly, no matter what story this determinist tells us about the brain state I am in, it must contain a qualification that if I wanted to do something different from what I now want I would be in a different brain state. The conclusion is that no matter what brain state I am in, "it is not a state such that if I wanted to strangle the kitten I could not". So physiological determinism is compatible with freedom as a power to do otherwise if one wants to ${ }^{8}$.

6. In the third stage, I will try to show that the two previous stages do not capture Hume's position about freedom, or what I take to be the fundamentals of it. The crucial notion to get Hume right in the third stage is that of motives which have a "uniform and regular influence" on the mind. It is because Hume gives prime of place to this notion that he asserts that "the doctrines, both of necessity and of liberty, [as he understands them], are not only consistent with morality, but are absolutely essential to its support" (E p.97).

Let us start by paying attention to the following text by Hume.

"[N]ecessity (...) has universally, though tacitly, in the schools, in the pulpit, and in common life, been allowed to belong to the will of man; and no one has ever pretended to deny that we can draw inferences concerning human actions, and that those inferences are founded on the experienced union of like actions, with like motives, inclinations, and circumstances. The only particular in which any one can differ, is, that either, perhaps, he will refuse to give the name of necessity to this property of human actions: But as long as the meaning is understood, I hope the word can do no harm: Or that he will maintain it possible to discover something farther in the operations of matter. But this, it must be acknowledged, can be of no consequence to morality or religion, whatever it may be to natural philosophy or metaphysics. We may here be mistaken in asserting that there is no idea of any other necessity or connexion in the actions of body: But surely we ascribe nothing to the actions of the mind, but what everyone does, and must readily allow of. We change no circumstance in the received orthodox system with regard to the will, but only in that with regard to material objects and causes. Nothing, therefore, can be more innocent, at least, than this doctrine" (E p.97).

8 I guess this would be a compatilism with a non sequitur according to Annette Baier (A Progress of Sentiments, Reflections on Hume's Treatise, Cambridge, Harvard UP, 1991) p.309n3. This compatiblism would be trying to find meaning to "could have done otherwise". 
This is an important text for the view I want to uphold. It is crucial that it should not be misunderstood. One certainly could be willing to take it as evidence for the vision of Hume presented in the second stage, but this would be a mistake. What does Hume intend? Because of what exactly does he think that he can claim that his doctrine is "innocent"?

Hume is prepared from what he says in this text to entertain, at least in hypothesis, that his account of the necessity in the actions of bodies is wrong, but he is not prepared to consider that what he said happens with the actions of the mind is a position which goes against "what everyone does, and must readily allow of". What is it? That there is mental necessity. But what does that mean exactly? That it is an objective, real, phenomenon that which in general we could call mental causation. What is implied by this text then? (1) That, in view of the point that perhaps there is something more of necessity or connexion in the actions of bodies, we should distinguish at least in this context between (a) the operations of external objects and (b) the operations of internal objects. (2) That the point of the insistence on the feature of the necessity of the operations of the internal objects is not esoteric, is not special, is not philosophical. On the contrary, it is ordinary, pedestrian. It concerns a phenomenon that we should be able to recognize ordinalrily. Therefore, putting the two points together, we reach the consideration that whatever "new result" concerning the necessity in matter is to be found, it will not have any consequence for morality and religion, which presumably do occupy themselves only with these internal objects, even though this could be an important result for natural philosophy — and Hume says - "or metaphysics". In the Treatise, Hume denies that he is asserting "the necessity of human actions, and plac[ing] them on the same footing with the operations of senseless matter. I do not ascribe to the will that unintelligible necessity which is suppos' $d$ to lie in matter" (T p.410).

What evidences, to be gathered from other parts of the text, can be presented for this reading of the present passage?

Let us first note the text that follows in the immediate sequence. I will comment on its two parts. My objective is to make salient what for Hume is the object of moral evaluation, to wit, personal character.

a) "The only proper object of hatred or vengeance is a person or creature, endowed with thought and consciousness; and when any criminal or injurious actions excite that passion, it is only by their relation to the person, or connexion with him. Actions are, by their very nature, temporary and perishing; and where they proceed not from some cause in the character and disposition of the person who performed them, they can neither redound to his honour, if good; nor infamy, if evil" (E p.98). 
This passage looks tailor-made for the understanding of Hume which makes all the interest of his views on liberty to reside in, let me put it this way, the "metaphysical" causal analysis of action. Furthermore, it would be through the connexion of actions with their causes in the person that it would be possible to have the phenomenon of moral responsibilization, and consequently morality could be studied through a science of men. This is Barry Stroud's reading". Now, it is true that Hume enphasizes the "cause" of actions in this part of his text, but I believe that what is crucial comes next.

b) "The actions themselves may be blameable; they may be contrary to all rules of morality and religion: But the person is not answerable for them; and as they proceeded from nothing in him that is durable and constant, and leave nothing of that nature behind them, it is impossible he can, upon their account, become the object of punishment or vengeance. According to the principle, therefore, which denies necessity, and consequently causes, a man is as pure and untainted, after having committed the most horrid crime, as at the first moment of his birth, nor is his character anywise concerned in his actions, since they are not derived from it, and the wickedness of the one can never be used as a proof of the depravity of the other" (E p.98).

What I take Hume to be saying here is that we have to rely on mental causation. In the Treatise, Hume expresses himself more clearly when he says that there is an influence of rewards and punishments on the behaviour of men and that "[w]e can give to this influence what name we please; but as 'tis usually conjoin' $d$ with action, common sense requires it shou' $d$ be esteem' $d$ a cause, and look'd upon as an instance of the necessity, which I wou'd establish" (T p.410). Hume insists on cause in this context of his dealings with the "internal objects" because this is his way of making sure that we will concentrate on what for him is the proper object of moral evaluation: that which in people is "durable and constant", that is, their character. In the Treatise, this is presented as that thing which is durable in the person, something that concerns the "sensible and thinking part" (T p.349). The point I take Hume to be making here is that actions have to reveal that "part" so that they may play a role in the moral evaluation of the person. The motives and principles revealed in the intentions with which we make our actions are what constitute those durable, persistent, qualities (not necessarily unchangeable ${ }^{10}$ ) that characterize us as persons (and there is no need for the actions to be characteristic actions $\left.^{11}\right)$.

9 Cf. Hume (London: Routledge, 1981), p.150.

10 Cf. John Bricke, op.cit., pp.184-5.

11 Cf. ibidem, p.189 and John Bricke, "Hume's Conception of Character" in: Tweyman, S. (ed.): David Hume, Critical Assessments (Vol. VI) (London: Routeledge, 1995), pp.248-54. 
In the next paragraph I believe Hume is even more clear:

\begin{abstract}
"Men are not blamed for such actions as they perform ignorantly and casually, whatever may be the consequences. Why? But because the principles of these actions are only momentary, and terminate in them alone. Men are less blamed for such actions as they perform hastily and unpremeditately than for such as proceed from deliberation. For what reason? but because a hasty temper, though a constant cause or principle in the mind, operates only by intervals, and infects not the whole character. Again, repentance wipes off every crime, if attended with a reformation of life and manners. How is this to be accounted for? But by asserting that actions render a person criminal merely as they are proofs of criminal principles in the mind; and when, by an alteration of these principles, they cease to be just proofs, they likewise cease to be criminal. But, except upon the doctrine of necessity, they never were just proofs, and consequently never criminal" (E pp.98-9).
\end{abstract}

Hume's point: moral evaluations should be of the "whole character", which is composed of "principles" that may criminal, but that may be removed as well, but not too easily, given that it requires nothing less than a "reformation of life and manners" 12 .

I would like to go back to a text already mentioned. I do it with the aim of attenuating an impression which this text could cause, i.e. to the effect that Hume would be interested only in uniformity. It is that text about the supposed proof of the "liberty of indifference" (E p.94n1). What would be Hume's main point there? That the perspective of the first person about actions, that is, our perspective in relation to our own actions, is misleading. When we act, and not when we contemplate what is being done by others, we are inclined to think that we are not determined to do anything, we "imagine we feel, that the will itself is subject to nothing". Well, Hume would be saying that things are not like that. He would introduce the point of view of a spectator. Hume says: "[I]t seems certain, that, however we may imagine we feel a liberty within ourselves, a spectator can commonly infer our actions from our motives and character; and even where he cannot, he concludes in general, that he might, were he perfectly acquainted with every circumstance of our situation and temper, and the most secret springs of complexion and disposition. Now this is the very essence of necessity, according to the foregoing doctrine". The point that he would be making here is: that there is something there to be known, it is complex, hidden and secret, but it is there in the agent.

What I would like to hold about this is that it is an exageration on Hume's part, that he exagerates the resemblances between the operation of "motives

12 The picture is much more detailed in the Appendix 4 to the EPM, pp.321-2. Cf. Baier, op.cit., pp.155, 157. Cf. also Rupert Read, "Review of Rosalind Hursthouse's On Virtue Ethics" in: Philosphical Investigations, Vol.24 NO.3, (Oxford, Blackwell, July 2001), pp.274-82. 
and principles" in agents and the "hidden and secret causes" in, say, the mechanisms of clocks. If we pay attention to the context in which this case is dealt with, the context in which several uniformities are presented, and ask what is the point being made in, for example, uniformity "e" quoted above, that is, what is it that we want to know in this case, what type of knowledge is this and on what does it depend, I think we can reach a different perspective on the matter. Let's consider the following.

Firstly, Hume says that the most irregular and unexpected resolutions may frequently be explained by those who know more. The suggestion which I think should be resisted here is that the notion is statistical. It is rather crucial that they are not always explained, though they may frequently ${ }^{13}$.

Secondly, the type of information those people who know more - and perhaps, as the case may be, best - would have is not theoretical, it does not depend on any theory. On the contrary, it is pedestrian: the person has got toothache or has not dined (this goes for hte knowing more only).

Hume says, crucially, that "we know, in general, that the characters of men are, to a certain degree, inconstant and irregular" (E p.88). This Hume does not say with the intention of risking what he held on the uniformity of human motivations and actions. Uniformity in human actions is crucial for our "collect[ing] any general observations concerning mankind", observations which are the basis for our regulation of "future conduct" (cf. E pp.84-5). (And in this context Hume also speaks of "experiments" which could induce us to think that he has the scientific sense of the word in mind). But there is something else here: experience (and it doesn't seem to be scientific) digested by reflection. It is at this place that Hume mentions the "aged husbandman" who seems to know more of his calling because he has spent more time doing it carefully and has learned of the complexity of uniformity in the operation of the sun, rain, earth and vegetables. Hume seems to be saying that this person has learned true generalizations. But, firstly, he speaks at this point of "rules" only, and in this context there may be at most "maxims". And this seems to be telling at such a juncture. However, we should pay attention to what Hume in the sequence does not want by any means to risk: "We must not, however, expect that this uniformity of human actions should be carried to such a length as that all men, in the same circumtances, will always act precisely in the same manner, without making any allowance for the diversity of characters, prejudices, and opinions" (E p.85). Now, this — though it may seem so — is not a

13 Cf. John Hyman on the statistical use of "typically" in conncetion with the temptation to ask why we typically mistake an illusion for a perception ("The Causal Theory of Perception" in: The Philosophical Quarterly, Vol.42 No. 168 July 1992, pp.286-7). 
kind of concession to the irregularity in the operations of a part of nature due to "minuteness or remoteness" or to complexity as in the case of the human body. At this place, Hume, in spite of the uniformity introduced also by "custom and education" (E p.86), seems to admit that there is something ineradicable about "motives and principles" of intelligent agents. Hume does not turn that which is "internal" into a mechanism.

\section{Bibliography}

BAIER, Annette: A Progress of Sentiments, Reflections on Hume's Treatise, Cambridge, Harvard UP, 1991.

BRICKE, John: "Hume, Freedom to Act, and Personal Evaluation" in: Tweyman, S. (ed.): David Hume, Critical Assessments (Vol. IV) London: Routledge, 1995: pp.175-91

BRICKE, John: "Hume's Conception of Character" in: Tweyman, S. (ed.): David Hume, Critical Assessments (Vol. VI) London: Routeledge, 1995: pp.248-54.

DAVIDSON, Donald: “Acions, Reasons, and Causes" in: Essays on Actions and Events, Oxford: Clarendon Press, Oxford UP, 1980.

DAVIDSON, Donald: "Mental Events" in: Essays on Actions and Events, Oxford: Clarendon Press, Oxford UP, 1980.

GEACH, Peter: "Intention, Freedom and Predictability" in: Teichmann, R. (ed): Logic, Cause and Action, Essays in Honour of Elizabeth Anscombe, Cambridge: Cambridge UP, 2000.

HUME, David: A Treatise on Human Nature, Oxford, Oxford: Clarendon Press, 1978. HUME, David: Enquiries concerning Human Understanding and concerning the Principles of Morals, Oxford, Oxford: Clarendon Press, 1975.

HYMAN, John: “The Causal Theory of Perception" in: The Philosophical Quarterly, Vol.42 No. 168 July 1992.

KENNY, Anthony: The Metaphysics of Mind, Oxford: Oxford UP, 1992.

READ, Rupert: "Review of Rosalind Hursthouse's On Virtue Ethics" in: Philosphical Investigations, Vol.24 NO.3, (Oxford, Blackwell, July 2001), pp.274-82.

SCHNEEWIND, Jerome: The Invention of Autonomy, Cambridge, Cambridge U.P., 1998.

STROUD, Barry: Hume, London: Routledge, 1981. 